\title{
An Overview of Neurological Disorders in Wales
}

\section{Layla Jader}

The National Public Health Service for Wales, Cardiff, Wales, UK

\section{Key Words}

Neurological disorders, incidence and prevalence •

Commissioning $\cdot$ Wales

\begin{abstract}
This pragmatic work was undertaken to assist commissioners of health services in Wales in their planning for future provision of services for neurological and neurosurgical patients. A literature search, which was carried out to ascertain the epidemiology of neurological and neurosurgical disorders in Wales, revealed limited epidemiological surveys of patients in Wales, while other literatures although outdated were still relevant. More recent national reports, published by professional bodies and patients' organisations, were also identified. These disorders were also grouped according to their aetiology and symptoms into 13 groups. Using all the available literature, total estimates of annual incidence and point prevalence of these disorders were arrived at. We can conclude that approximately $5.8 \%$ of the population in Wales are affected by neurological and neurosurgical disorders that include headaches, traumatic and infectious diseases of the nervous system.
\end{abstract}

Copyright $\odot 2007$ S. Karger AG, Base

\section{Introduction}

There are a large number of neurological disorders; some are very common and dealt with by specialties other than neurology and neurosurgery. The majority of stroke patients in the UK never come into contact with a neurologist, and patients with multiple problems, often the elderly, are usually looked after by care-of-the-elderly physicians, even when there is a neurological component such as Parkinson's disease and stroke [1]. Other core neurological and neurosurgical disorders, whilst rare, when aggregated constitute a significant part of the National Health Service (NHS) work. Around 200 people in a population of 100,000 are likely to develop a specific condition such as Parkinson's disease each year, and only 3 in a population of 100,000 experience a traumatic spinal injury every year [2]. Neurological and neurosurgical conditions account for $10 \%$ of visits to accident and emergency departments, and are the third most common reason for attending a family doctor [3]. In Wales in 2001/02, diseases of the nervous system constituted $2.3 \%$ of allcauses finished consultant episodes and up to $13 \%$ of all GP referrals in 2000 [4].

An estimated 17,500 people across Wales need help with activities of daily living as a result of a neurological condition, and 42,500 people care for someone with a neurological condition [3].

\section{KARGER \\ Fax +41613061234 E-Mail karger@karger.ch} www.karger.com
Dr. L. Jader

Consultant in Public Health Medicine, The National Public Health Service for Wales Temple of Peace and Health, Cathays Park Cardiff CF10 3NW (UK)

Tel. +44 292040 2463, Fax +44292040 2504, E-Mail Layla.Jader@nphs.wales.nhs.uk 
A literature search was carried out for seminal reports and publications on the frequency of neurological, neuromuscular and neurosurgical cases, in an attempt to estimate the total burden of these disorders. This work was undertaken to assist commissioners in planning for neurological and neurosurgical services in Wales. This paper presents an overview of the estimated frequency of these disorders as reported by various national and international publications and databases.

Two of the key measurements that are normally used in descriptive epidemiology are the prevalence and incidence of a disease [5]. The prevalence measures the number of current cases of a disease in a defined population at a given time and place. The incidence, on the other hand, is the number of new cases occurring in a defined population, a given place and for a given time interval, usually per year. For rare disorders data may have to be accumulated over several years to be able to state an incidence with an acceptable precision.

Both rates require the precise case definition and ascertainment of all cases of the disease in the target population and this is not always feasible or logistically possible. The population also need to be precisely defined, as many of these disorders, some of which are genetic, vary according to ethnicity and are affected by population mix.

Another term that describes prevalence is the lifetime prevalence, which is the proportion of persons manifesting a disorder during the period of their life up to the survey date; usually this is described as per 1,000 of the population at risk, but it has been reported here per 100,000 to help comparison with other frequency measures and provide meaningful data for the commissioners and providers of health services [6]. Lifetime prevalence depends on the age distribution of those we study, and it is very likely to increase with age. It also requires a strong assumption that the age-specific incidence does not alter with time and cohort. This is probably plausible for Huntington's disease but not many other neurological disorders.

\section{Methodology}

Literature search was carried out for seminal publications and databases on the incidence and the prevalence of neurological, neuromuscular and neurosurgical disorders. Sources included: (1) general medical databases - Medline and Embase, integrated bibliographic text-based search and retrieval databases containing journal citations and extracts; (2) Social Care - Social Care Online, an extensive database of social care information; (3) quality-assured Internet gateways - OMNI, a searchable catalogue of select evaluated health and medicine internet resources; and (4) Frequency of Inherited Disorders Database (FIDD, Cardiff
University), a repository of data from published literature on the frequency of inherited human disorders worldwide, a first and only such database, but incomplete and has not been updated since 2002 due to funding problems.

The search used terms, MeSH and key words that included: incidence, prevalence, point prevalence, lifetime prevalence of various neurological disorders. All searches were limited to the English language. Authoritative and accredited professional organisational websites were also checked for their publications, including the Association of British Neurologists, the British Neuroscience Association, Neurological Alliance, Neurology-Related Websites and the Frequency of Inherited Disorders Database. The Internet was also scanned through Google as a scoping exercise, using filters to retrieve official NHS, government and academic sources.

Neurological disorders are categorised in this paper into 13 main aetiological and symptom-related groups, including a miscellaneous one of the very rare disorders. They are the infectious, traumatic, headache and migraine, vascular, paroxysmal and convulsive, neuropathies, degenerative, extrapyramidal, genetic, neoplastic, immunological and neuromuscular groups.

Three review articles and a book, which were frequently cited in the literature, in addition to the Frequency of Inherited Disorders Database, were primarily used for this overview [2, 6-9] to extract relevant annual incidence and prevalence rates per 100,000 population. In addition, other sources were identified and it became clear that this information is not complete and methods used to survey patients by various researchers over wide periods of time are not uniform.

\section{Results}

Table 1 shows the estimated rates of various neurological disorders and their sources, classed into 13 aetiological groups with the total estimates of each group. In addition to the 5 sources of references already mentioned, others were also found [10-19, 22-27]. The paper by Cockerell et al. [7] was based on surveys carried out in 1966, 1975, 1982, 1986 and 1992, and the same rates were also reported in the Association of British Neurologist report in 1997 [1]. The study by MacDonald et al. [2] was based on an urban population of London covering 13 general practices, with only $80 \%$ of their population being white, compared with the UK at $94 \%$ in 1994 . The article by Kurtzke [6] and the textbook by Batchelor and Cudkowicz [8] covered data reported elsewhere. The FIDD on the other hand is an international repository of publications on the frequency of inherited disorders [9]. When the rate of a particular disorder is quoted differently by different sources, value judgement was used in deciding which one to use to calculate the overall estimated accumulated annual incidence and point prevalence rates at the bottom of each system on table 1 . These final rates are also used in tables 2 and 3. 


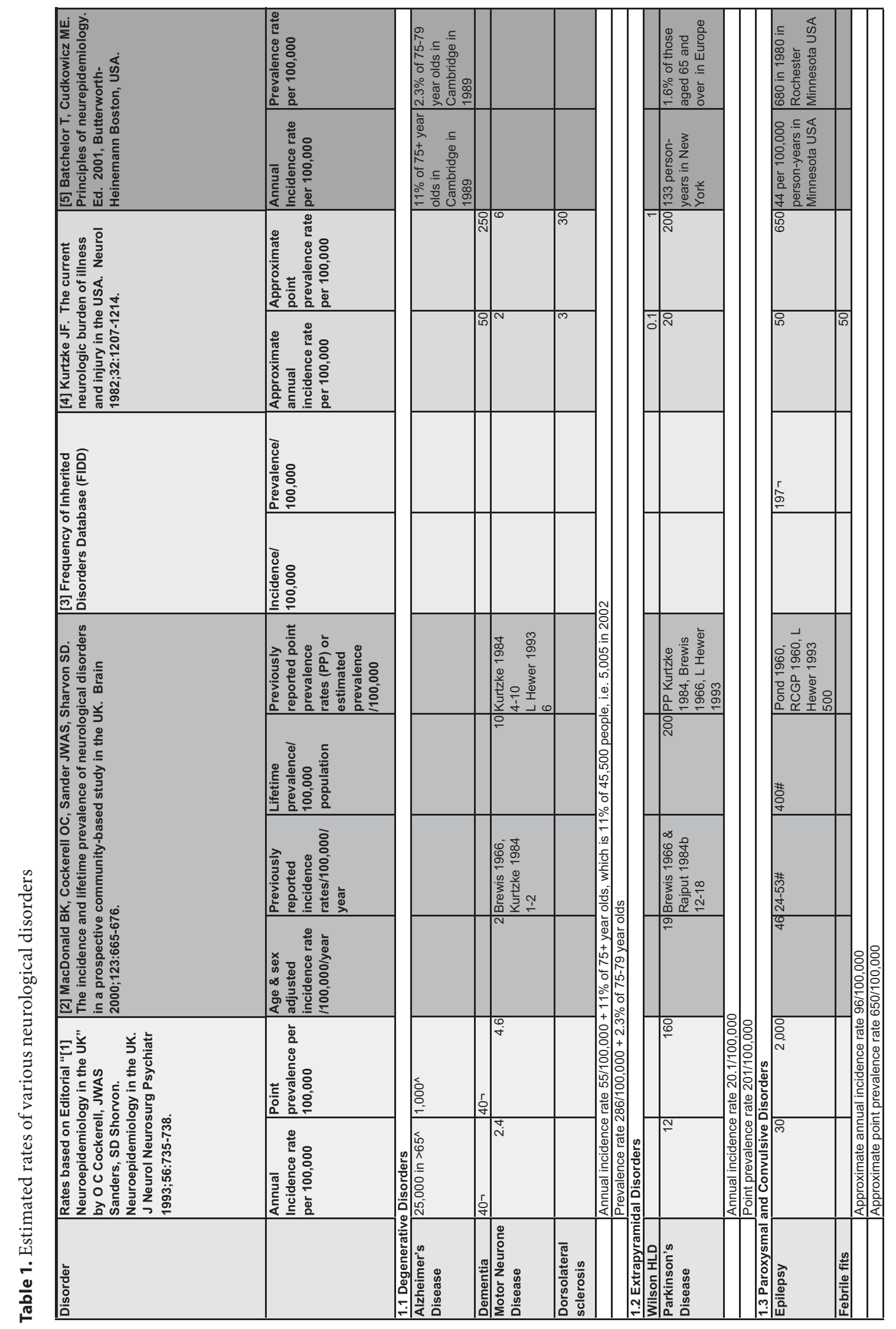




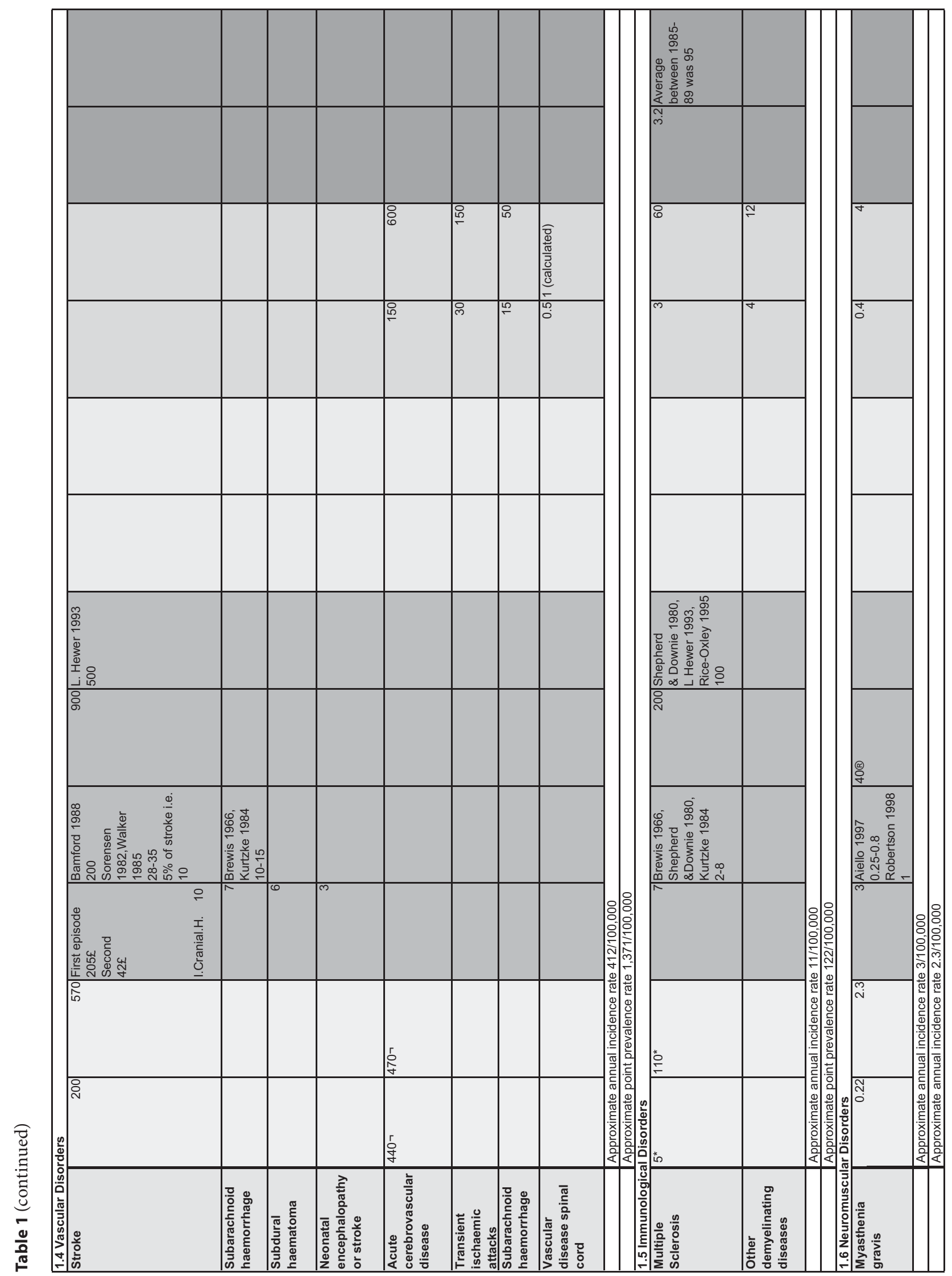




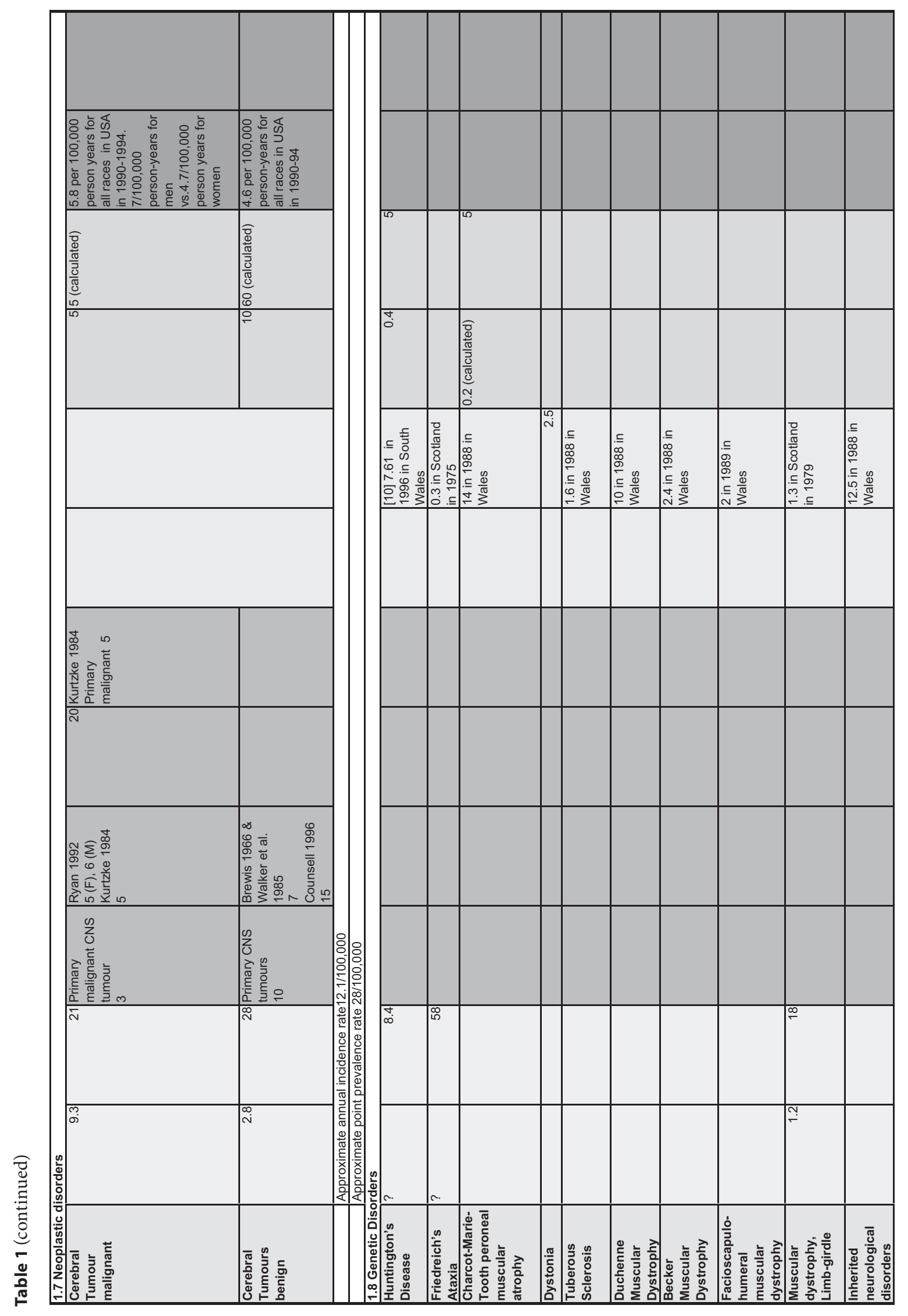




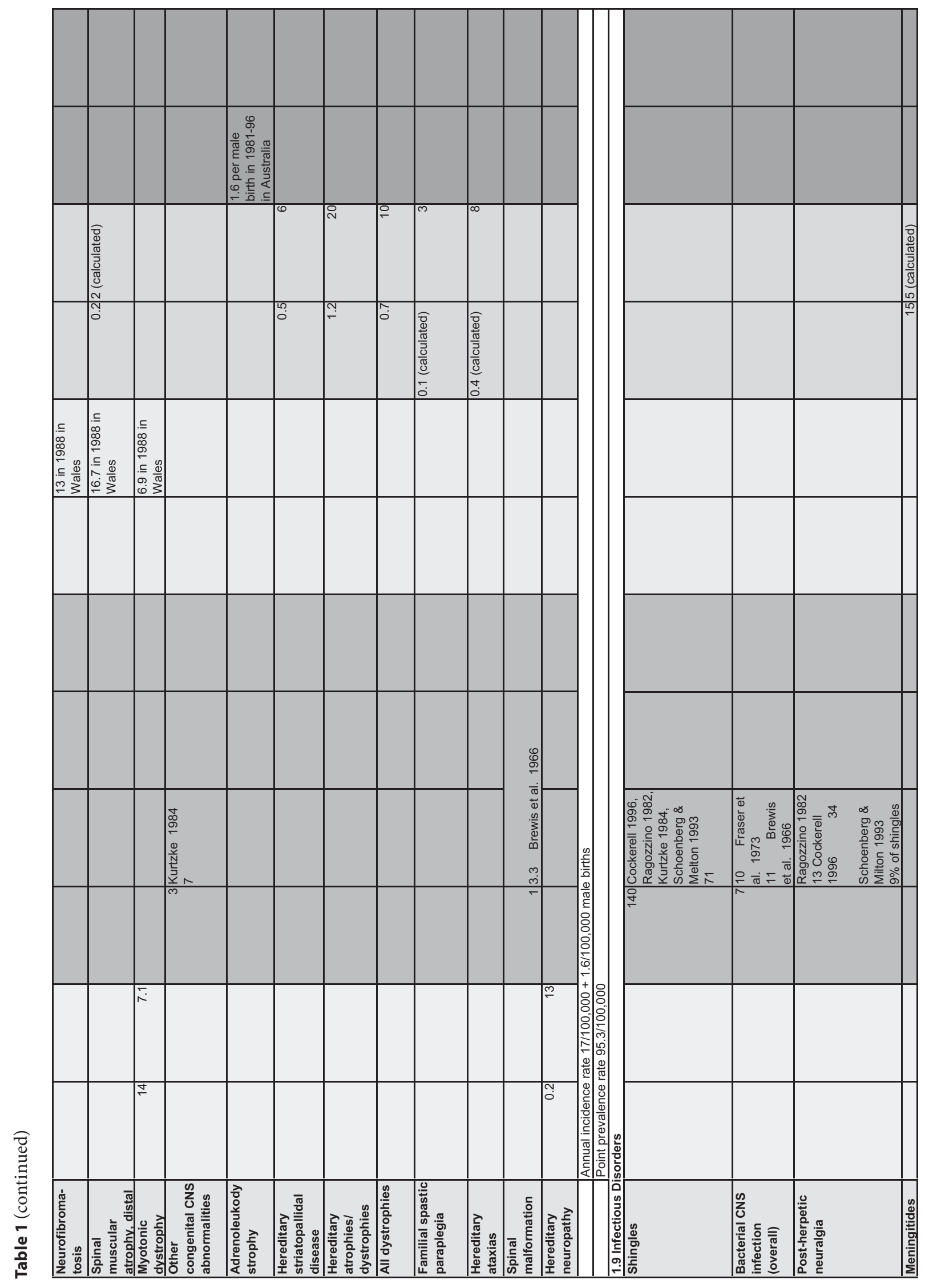




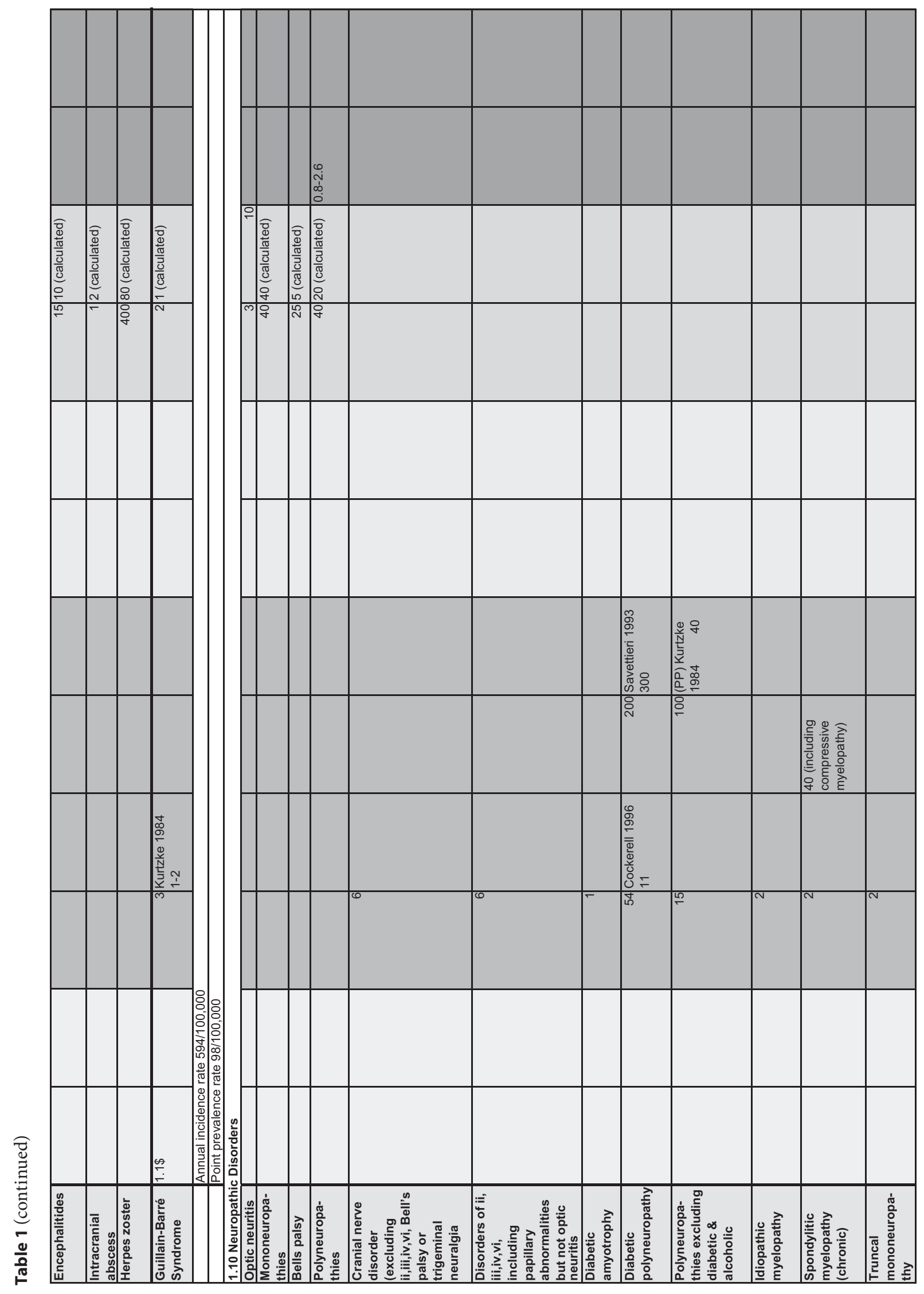




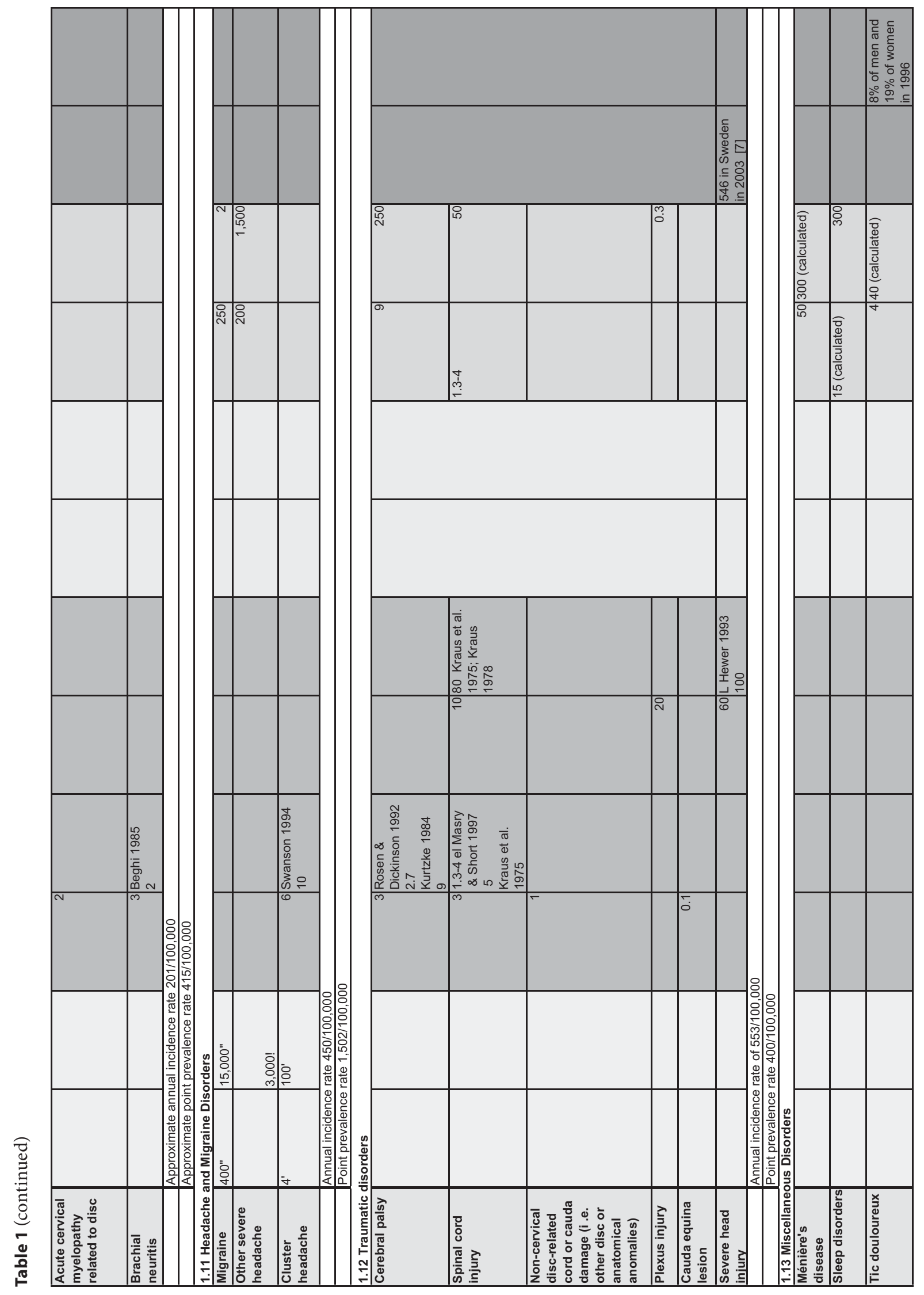




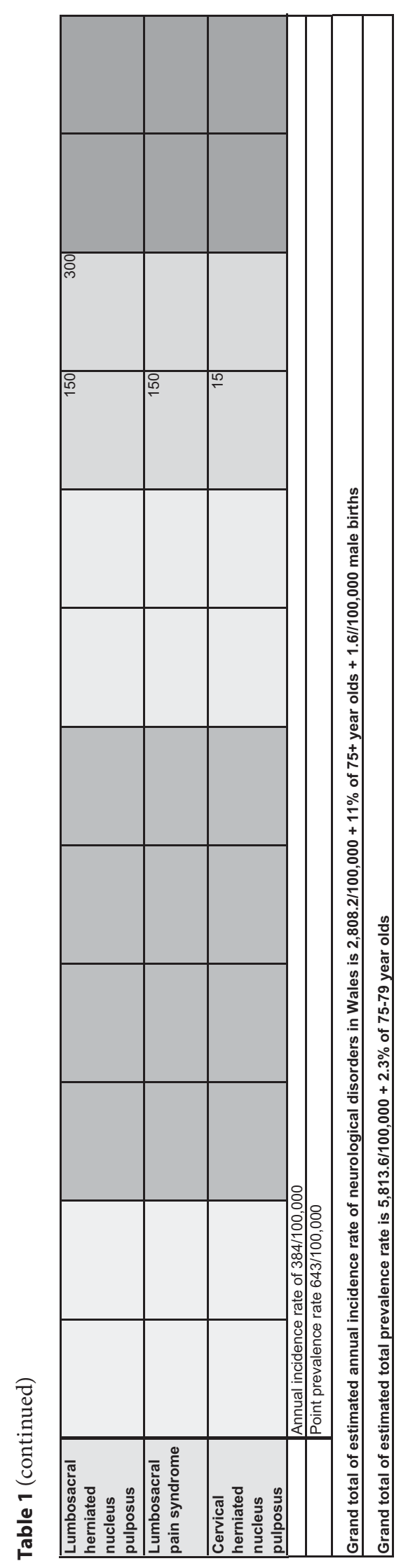

Neurological Disorders in Wales

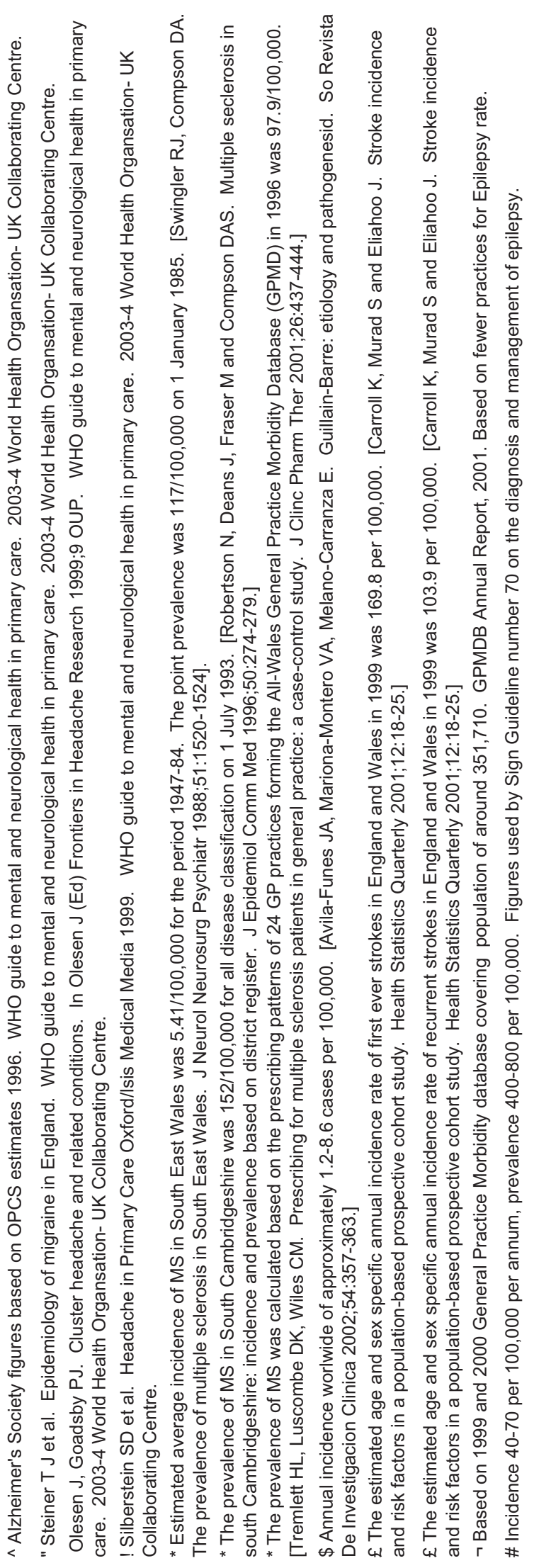


Table 2. Estimated accumulated annual incidence rates of various groups of neurological disorders

\begin{tabular}{lll}
\hline Neurological disorders & Estimated annual incidence rate/100,000 \\
\hline 1 & Infectious & 594 \\
2 & Traumatic & 553 \\
3 & Headache and migraine & 450 \\
4 & Vascular & 412 \\
5 & Miscellaneous & 384 \\
6 & Neuropathies & 201 \\
5 & Paroxysmal and convulsive disorders & 96 \\
7 & Degenerative & $55+11 \%$ of $75+$ year-olds \\
9 & Extrapyramidal syndromes & 20.1 \\
10 & Genetic & $17+1.6 / 100,000$ male births \\
11 & Neoplastic & 12.1 \\
12 & Immunological & 11 \\
13 & Neuromuscular (except genetics) & 3 \\
\hline & Total & $2,808.2 / 100,000+11 \%$ of $75+$ year-olds \\
& & $+1.6 / 100,000$ male births \\
\hline
\end{tabular}

Table 3. Estimated accumulated point prevalence rates of various groups of neurological disorders

\begin{tabular}{lll}
\hline Neurological disorders & Estimated prevalence rate/100,000 \\
\hline 1 & Headache and migraine & 1,502 \\
2 & Vascular & 1,371 \\
3 & Paroxysmal and convulsive disorders & 650 \\
5 & Miscellaneous & 643 \\
6 & Neuropathies & 415 \\
4 & Traumatic & 400 \\
7 & Degenerative & $286+$ Alzheimer's disease at $2.3 \%$ of \\
& & 75 - to 79 -year-olds $(1,047$ for the 45,500 \\
& & people of this age group in Wales in 2002$)$ \\
8 & Extrapyramidal syndromes & 201 \\
9 & Immunological & 122 \\
10 & Infectious & 98 \\
11 & Genetic & 95.3 \\
12 & Neoplastic & 28 \\
13 & Neuromuscular (except genetics) & 2.3 \\
\hline & Total & $5,813.6 / 100,000+2.3 \%$ of 75 - to \\
& & 79 -year-olds
\end{tabular}

For example, rates quoted by Kurtzke [6] were used for the degenerative system overall rates, as it was the only publication that also covered dorsolateral sclerosis, and for motor neurone disease the figures quoted by all the papers were very close, hence Kurtzke [6] rate was also used and similarly for dementia. Added to that were rates for Alzheimer's disease, which was only quoted by Batchelor and Cudkowicz [8]. Another example is the incidence rate for epilepsy, which was: 30,46 and 50; the middle figure 46 was taken when calculating the total rate.

Table 2 shows the estimated accumulated annual incidence rates of neurological disorders grouped by aetiology in a chronological order based on data from table 1 . The list is not exhaustive; hence these figures may underestimate the total burden. 
Table 4. Estimated number of patients with neurological disorders in Wales in descending order of prevalence

\begin{tabular}{|c|c|c|c|c|c|c|}
\hline Disorder & $\begin{array}{l}\text { Incidence of } \\
\text { estimated new } \\
\text { cases in Wales } \\
\text { based on refs. } 7 \text {, } \\
20 \text { and reported in } \\
\text { ref. } 21\end{array}$ & $\begin{array}{l}\text { Prevalence of } \\
\text { estimated total } \\
\text { number of cases } \\
\text { in Wales based on } \\
\text { refs. } 7,20 \text { and } \\
\text { reported in ref. } 21\end{array}$ & $\begin{array}{l}\text { Number with } \\
\text { significant } \\
\text { disability } \\
{[21]}\end{array}$ & $\begin{array}{l}\text { Estimated number } \\
\text { of patients in } 1995 \\
\text { taken from national } \\
\text { survey of } 20 \text { patient } \\
\text { organisations that } \\
\text { make up the } \\
\text { Neurological } \\
\text { Alliance [21] }\end{array}$ & $\begin{array}{l}\text { Al-Jader et al. [9] } \\
\text { (FIDD) }\end{array}$ & $\begin{array}{l}\text { Estimated number of } \\
\text { patients [7] }\end{array}$ \\
\hline Epilepsy & 2,042 & 45,513 & 15,151 & 21,000 & & $\begin{array}{l}\text { prevalence } \sim 19,842 \\
\text { based on USA, } 1980\end{array}$ \\
\hline Stroke & 6,419 & 17,505 & 10,503 & & & \\
\hline Alzheimer's disease & & & & 21,500 & & \\
\hline Head injury & 4,668 & & 8,753 & 4,200 disabled & & \\
\hline Parkinson's disease & 525 & 4,668 & 3,911 & 6,250 & & \\
\hline Dementia & & & & & & $\begin{array}{l}\text { annual incidence } 5,373 \\
\text { point prevalence } 2,511 \\
\text { patients }\end{array}$ \\
\hline Multiple sclerosis & 117 & 2,917 & 1,459 & 4,250 & & $\begin{array}{l}\text { prevalence } \sim 2,772 \\
(1985-89 \text { in USA }) \\
\text { annual incidence } \sim 93 \\
\text { cases }\end{array}$ \\
\hline Dystonia & & & & 1,900 & $\begin{array}{l}\text { incidence } 1: 40,000 \\
\text { USA Jews; estimated } \\
73 \text { patients }[22]\end{array}$ & \\
\hline Spinal injury & 35 & 1,750 & 1,751 & & & \\
\hline $\begin{array}{l}\text { Duchenne muscular } \\
\text { dystrophy }\end{array}$ & & & & 1,000 & $\begin{array}{l}\text { prevalence } 1: 10,000 \text { in } \\
1988 \text { in Wales; } \\
\text { estimated } 292 \text { patients } \\
{[10]}\end{array}$ & $\begin{array}{l}\text { annual incidence } 35 \\
\text { patients and point } \\
\text { prevalence } 526 \text { patients }\end{array}$ \\
\hline Cerebral tumour & 467 & 1,319 & 467 & & & \\
\hline $\begin{array}{l}\text { Guillain-Barré } \\
\text { syndrome }\end{array}$ & 35 & 700 & 140 & & & \\
\hline Tuberous sclerosis & & & & 455 & $\begin{array}{l}\text { prevalence } 1: 62,500 \text { in } \\
1988 \text { in Wales; } \\
\text { estimated } 46 \text { patients } \\
{[10]}\end{array}$ & \\
\hline $\begin{array}{l}\text { Huntington's } \\
\text { disease }\end{array}$ & & 175 & 175 & 420 & $\begin{array}{l}\text { prevalence } 1: 16,129 \text { or } \\
86 \text { patients in } 1994 \\
{[23]}\end{array}$ & \\
\hline $\begin{array}{l}\text { Motor neurone } \\
\text { disease }\end{array}$ & 58 & 175 & 163 & 300 & & $\begin{array}{l}\text { prevalence } \sim 117-175 \\
\text { patients }\end{array}$ \\
\hline Myasthenia gravis & 12 & 117 & & & & $\begin{array}{l}\text { annual incidence } 6 \\
\text { patients, point } \\
\text { prevalence } 67 \text { patients }\end{array}$ \\
\hline Friedreich's ataxia & & 58 & 58 & & $\begin{array}{l}\text { prevalence } 1: 322,581 \\
\text { Scotland in } 1975 ; \\
\text { estimated } 90 \text { patients } \\
{[24]}\end{array}$ & \\
\hline $\begin{array}{l}\text { Charcot-Marie- } \\
\text { Tooth peroneal } \\
\text { muscular atrophy }\end{array}$ & & & & 60 & $\begin{array}{l}\text { prevalence } 1: 6,900 \text { in } \\
1988 \text { in Wales; } \\
\text { estimated } 423 \text { patients } \\
{[25]}\end{array}$ & \\
\hline
\end{tabular}


Table 4 (continued)

\begin{tabular}{|c|c|c|c|c|c|c|}
\hline Disorder & $\begin{array}{l}\text { Incidence of } \\
\text { estimated new } \\
\text { cases in Wales } \\
\text { based on refs. } 7 \text {, } \\
20 \text { and reported in } \\
\text { ref. } 21\end{array}$ & $\begin{array}{l}\text { Prevalence of } \\
\text { estimated total } \\
\text { number of cases } \\
\text { in Wales based on } \\
\text { refs. } 7,20 \text { and } \\
\text { reported in ref. } 21\end{array}$ & $\begin{array}{l}\text { Number with } \\
\text { significant } \\
\text { disability } \\
{[21]}\end{array}$ & $\begin{array}{l}\text { Estimated number } \\
\text { of patients in } 1995 \\
\text { taken from national } \\
\text { survey of } 20 \text { patient } \\
\text { organisations that } \\
\text { make up the } \\
\text { Neurological } \\
\text { Alliance [21] }\end{array}$ & $\begin{array}{l}\text { Al-Jader et al. [9] } \\
\text { (FIDD) }\end{array}$ & $\begin{array}{l}\text { Estimated number of } \\
\text { patients [7] }\end{array}$ \\
\hline
\end{tabular}

Progressive supra-

50

nuclear palsy

Becker muscular
dystrophy incidence 1:41,667 in

1988 in Wales;

estimated 70 patients

[10]

prevalence 1:50,000 or

56 cases in 1989 in

Wales [26]

humeral muscular

dystrophy

Muscular

dystrophy,

limb-girdle

\section{Inherited}

neurological

disorders

Neurofibro-

matosis

60

prevalence $1: 76,900$ in

Scotland in 1979;

estimated 38 patients

[27]

prevalence 1:8,000 in

1988 in Wales;

estimated 365 patients

[10]

prevalence $1: 7,500$ in

1988 in Wales;

(2)

estimated 389 patients

[10]

Spinal muscular

atrophy, distal

prevalence 1:6,000 in

1988 in Wales;

estimated 487 patients

[10]

incidence $1: 14,500$ in

1988 in Wales;

annual incidence 408

estimated 201 patients

[10]

Hereditary

neuropathy

Polyneuropathies

Very rough

14,378

estimate

of number

of patients patients, point

prevalence 207 patients

annual incidence 6

patients, point

prevalence 380 patients
2,251 (prevalence and incidence of genetic neurological disorders from FIDD); if we add hereditary neuropathies from

Cockerell et al. [7]

then total is 2,631 
Table 3 shows the estimated accumulated point prevalence rates of various groups of neurological disorders, which is again not an exhaustive list.

Table 4 shows the estimated number of patients with neurological disorders who live in Wales in a descending order of prevalence. This was based on published incidence and prevalence rates, which were then adjusted using the Office of National Statistics 2002 mid-year estimate of the population of Wales of 2.918 millions. The number of patients with significant disabilities was arrived at from data in tables 1-3 and from various seminal reports and databases [7, 20, 21]. Epilepsy, stroke, Alzheimer's disease, head injury and Parkinson's disease form the most common disorders with the highest number of patients who are left with significant disability.

\section{Discussion}

This paper is a pragmatic attempt at summarising the available significant literature on the epidemiology of neurological and neurosurgical disorders. The epidemiology was presented in a format that was useful for the commissioners in Wales, both at an All Wales level for Health Commission Wales and for the Local Health Boards, as they develop their plan for service review.

Unfortunately, authoritative national and international review articles are relatively few and some are 15-23 years old. There are many neurological disorders and some are very rare. There is a dearth of published evidence on the frequency of many of the neurological disorders, especially the very rare.

When compared with other system disorders, most of the long-term neurological conditions have disproportionately higher percentages of physical, sensory, cognitive/behavioural and communication problems. All these problems have an impact on the psycho-social and emotional well-being of these patients.

The infectious or infection-related group of neurological disorders included many conditions that may never come to the attention of a neurologist such as meningitis, shingles and herpes zoster. They usually present to general practice, medical, geriatric or paediatric specialties. Similarly, some of the traumatic cases are usually seen in trauma and orthopaedics specialties. The rest of these disorders are chronic, intermittent and recurrent in nature. They are usually unpredictable such as epilepsy, headache or the early stages of multiple sclerosis.

There are also conditions with sudden onset such as brain and spinal injuries and those conditions that are progressive in nature such as motor neurone disease, Parkinson's disease or later stages of multiple sclerosis. There are also small groups of conditions that are stable, but with changing needs as the person ages, such as post-polio syndrome or cerebral palsy in the adults.

Table 1 includes a more exhaustive list of disorders reaching an estimated prevalence of grand total of $5,813.6 / 100,000$. Using ONS 2002 mid-year population estimates of Wales, the total was 169,682 patients plus Alzheimer's disease at $2.3 \%$ of 75 - to 79 -year-olds $(1,047 \mathrm{pa}$ tients) making a grand total estimate of 170,729 patients. This translates to $5.8 \%$ of the population in Wales having neurological or neurosurgical conditions in 2002. This is more than the prevalence of cancer and diabetes, respectively, both at 5\% according to the Welsh Health Survey 2003 and 1998 [National Assembly for Wales: Welsh Health Survey October 2003-March 2004, provisional results, unpublished], although the latter was based on 7,802 self-reporting 16 years and older people. However, patients with headaches, migraines and infectious conditions make a sizeable part of this total figure, and these conditions may not pose the individual resource implications that diabetes and malignant conditions pose.

A rough estimate of the number of patients with some of the main genetic neurological disorders is about 2,781 patients $(0.1 \%$ or $1: 1,049$ of the people of Wales and $1.64 \%$ of the total load of neurological disorders).

To reflect on the size of the problem for neurology and neurosurgery, which means excluding the infectious group apart from Guillain-Barré, we arrive at a total annual incidence rate of 2,214/100,000 (64,605 patients, $2.2 \%$ of the population, table 2 ).

Although neurosciences have had a relatively low profile particularly when compared with the high political, public and media profile that cancer and cardiac services receive, this overview has strengthened the argument that there is a need to adequately cater for this group of disorders that annually afflict 1:45 of people in Wales. 


\section{References}

1 UK Neurology: The Next Ten Years, Putting Patient First. London, The Association of British Neurologists, 2003.

$\checkmark 2$ MacDonald BK, Cockerell OC, Sander JWAS, Sharvon SD: The incidence and lifetime prevalence of neurological disorders in a prospective community-based study in the UK. Brain 2000;123:665-676.

3 Neuro Numbers, a Brief Review of the Numbers of People in the UK with a Neurological Condition. The Neurological Alliance, April 2003.

4 GP Morbidity Data Base Annual Report 2001.

5 Barker DJP, Coggon D, Rose G: Epidemiology for the Uninitiated, ed 4. London, BMJ Books, 1997.

6 Kurtzke JF: The current neurologic burden of illness and injury in the USA. Neurology 1982;32:1207-1214

7 Cockerell OC, Sander JW, Shorvon SD: Neuroepidemiology in the UK. J Neurol Neurosurg Psychiatry 1993;56:735-738.

8 Batchelor T, Cudkowicz ME: Principles of Neuroepidemiology. Boston, ButterworthHeinemann, 2001.

$\checkmark 9$ Al-Jader LN, Harper PS, Krawczak M, Palmer SR, Johansen BN, Cooper DN: The Frequency of Inherited Disorders Database (FIDD). Hum Genet 2000;108:72-74.

10 MacMillan JC, Harper PS: Single-gene neurological disorders in South Wales: an epidemiological study. Ann Neurol 1991;30:411-414.

-11 Andersson EH, Bjorklund R, Emanuelson I, Stalhammar D: Epidemiology of traumatic brain injury: a population based study in western Sweden. Acta Neurol Scand 2003;107: 256-259.

$\checkmark 12$ Steiner TJ, Scher Al, Stewart WF, Kolodner K, Liberman J, Lipton RB: The prevalence and disability burden of adult migraine in England and their relationships to age, gender and ethnicity. Cephalalgia 2003;23:519-527.

13 Olesen J, Goadsby PJ: Cluster Headache and Related Conditions; in Olesen J (ed): Frontiers in Headache Research Series. Oxford, Oxford University Press, 1999, No 9.

14 Silberstein SD, et al: Headache in Primary Care. Oxford, Isis Medical Media, 1999.

15 Swingler RJ, Compson DA: The prevalence of multiple sclerosis in South East Wales. J Neurol Neurosurg Psychiatry 1988;51:1520-1524.

-16 Robertson N, Deans J, Fraser M, Compston DAS: Multiple sclerosis in south Cambridgeshire: incidence and prevalence based on district register. J Epidemiol Community Health 1996;50:274-279.

$\checkmark 17$ Tremlett HL, Luscombe DK, Wiles CM: Prescribing for multiple sclerosis patients in general practice: a case-control study. J Clin Pharm Ther 2001;26:437-444.

- 18 Avila-Funes JA, Mariona-Montero VA, Melano-Carranza E: Guillain-Barré: etiology and pathogenesis (in Spanish). Rev Invest Clin 2002;54:357-363.

19 Carroll K, Murad S, Eliahoo J: Stroke incidence and risk factors in a population-based prospective cohort study. Health Statistics Q 2001;12:18-25.
20 Wade DT, Langton Hewer R: Epidemiology of some neurological diseases with special reference to workload on the NHS. Int Rehab Med 1987;8:129-137.

21 Association of British Neurologists: Neurol ogy in the United Kingdom: Towards 2000 and beyond. London, Association of British Neurologists, 1997.

22 Eldridge R, Edgar A, Cooper IS: Genetics, geography and intelligence in the torsion dystonias. Birth Defects, Orig Art Ser 1971;7:167177.

23 James CM, Houlihan GD, Snell RG, Cheadle JP, Harper PS: Late-onset Huntington's disease: a clinical and molecular study. Age Ageing 1994;23:445-448.

24 Koeppen AH, Hans MB, Shepherd DI, Best PV: Adult-onset hereditary ataxia in Scotland. Arch Neurol 1977;34:611-618.

25 MacMillan JC, Harper PS: Charcot-MarieTooth syndrome: clinical aspects from a population study in South Wales. Clin Genet 1994;435:128-134.

26 Lunt PW, Harper PS: Genetic counselling in facioscapulohumeral muscular dystrophy. Med Genet 1991;28:655-664.

27 Yates JRW, Emery AEH: A population study of adult onset limb-girdle muscular dystrophy. J Med Genet 1985;22:250-257.

28 Brewis M, Poskanzer DC, Rolland C, Miller $\mathrm{H}$ : Neurological disease in an English city. Acta Neurol Scand 1966;42(suppl 24):1-89.

29 Kurtzke JF: Neuroepidemiology. Ann Neurol 1984;16:265-277.

30 Langton Hewer R: The epidemiology of disabling neurological disorders; in Greenwood R, Barnes MP, McMillan TM, Ward CD (eds) Neurological Rehabilitation. Edinburgh, Churchill Livingstone, 1993, pp 3-12.

31 Rajput AH, Offord KP, Beard CM, Kurland LT: Epidemiology of parkinsonism: incidence, classification, and mortality. Ann Neurol 1984; 16:278-282.

32 Pond DA, Bidwell BH, Stein L: A survey of epilepsy in fourteen general practices. I. Demo graphic and medical data. Psychiatr Neurol Neurochir 1960;63:217-236.

33 Research Committee of the College of General Practitioners (RCGP): A survey of the epilepsies in general practice. BMJ 1960;ii:416422.

34 Bamford J, Sandercock P, Dennis M, Warlow $\mathrm{C}$, Jones L, McPherson $\mathrm{K}$, et al: A prospective study of acute cerebrovascular disease in the community, the Oxfordshire Community Stroke Project 1981-86. I. Methodology, demography and incident cases of first-ever stroke. J Neurol Neurosurg Psychiatry 1988; 51:1373-1380.

35 Sorensen SP, Boysen G, Jensen G, Schnohr P Prevalence of stroke in a district of Copenhagen. Acta Neurol Scand 1982;66:68-81.

36 Walker AE, Robins M, Weinfeld FD: Epidemiology of brain tumors, the national survey of intracranial neoplasms. Neurology 1985;35: 219-226.
37 Shepherd DI, Downie AW: A further prevalence study of multiple sclerosis in north-east Scotland. J Neurol Neurosurg Psychiatry 1980;43:310-315.

38 Rice-Oxley M, Williams ES, Rees JE: A prevalence survey of multiple sclerosis in Sussex. J Neurol Neurosurg Psychiatry 1995;58:27-30.

-39 Aiello I, Pastorino M, Sotgiu S, Pirastru MI, Sau GF, Sanna G, et al: Epidemiology of myasthenia gravis in northwestern Sardinia. Neuroepidemiology 1997;16:199-206.

40 Robertson NP, Dean J, Compston DA: Myasthenia gravis, a population based epidemiological study in Cambridgeshire, England. J Neurol Neurosurg Psychiatry 1998;65:492496.

41 Ryan P, Lee MW, North B, McMichael AJ: Risk factors for tumors of the brain and meninges, results from the Adelaide Adult Brain Tumor Study. Int J Cancer 1992;51:20-27.

42 Counsell CE, Collie DA, Grant R: Incidence of intracranial tumours in the Lothian region of Scotland, 1989-90. J Neurol Neurosurg Psychiatry 1996;61:143-150.

43 Cockerell OC, Goodridge DM, Brodie D, Sander JW, Shorvon SD: Neurological disease in a defined population: the results of a pilot study in two general practices. Neuroepidemiology 1996;15:73-82.

44 Ragozzino MW, Melton LJ 3d, Kurland LT, Chu CP, Perry HO: Population-based study of herpes zoster and its sequelae. Medicine 1982; 61:310-316.

45 Schoenberg BS, Melton LJ: Epidemiologic approaches to peripheral neuropathy; in Dyck PJ, Thomas PK, Griffin JW, Low PA, Poduslo JF (eds): Peripheral Neuropathy. Philadelphia, Saunders, 1993, pp 775-783.

46 Fraser DW, Henke CE, Feldman RA: Changing patterns of bacterial meningitis in Olmsted County, Minnesota, 1935-1970. J Infect Dis 1973;128:300-307.

47 Savettieri G, Rocca WA, Salemi G, Meneghini F, Grigoletto F, Mogante L, et al: Prevalence of diabetic neuropathy with somatic symptoms, a door-to-door survey in two Sicilian municipalities. Neurology 1993;43:1115-1120.

48 Beghi E, Kurland LT, Mulder DW, Nicolosi A: Brachial plexus neuropathy in the population of Rochester, Minnnesota, 1970-1981. Ann Neurol 1985;18:320-323.

49 Swanson JW, Yanagihara T, Stang PE, O'Fallon WM, Beard CM, Melton LJ 3rd, et al: Incidence of cluster headaches, a populationbased study in Olmsted County, Minnesota. Neurology 1994;44:433-437.

50 Rosen MG, Dickinson JC: The incidence of cerebral palsy. Am J Obstet Gynecol 1992;167: 417-423.

51 el Masry WS, Short DJ: Current concepts, spinal injuries and rehabilitation (review). Curr Opin Neurol 1997;10:484-492.

52 Kraus JF, Franti CE, Riggins RS, Richards D, Borhani NO: Incidence of traumatic spinal cord lesions. J Chronic Dis 1975;28:471-492.

53 Kraus JF: Epidemiological features of head and spinal cord injury (review). Adv Neurol 1978;19:261-279. 